\section{Biotechn seeks share of the credit}

\section{Washington}

Dr Robert Helling will formally press a claim of co-inventorship of the CohenBoyer genetic engineering patents (see Nature 11 November, p.95). Helling, now at the University of Michigan, worked with Dr Herbert Boyer at the University of California, San Francisco, during a sabbatical in 1972-73 and co-authored the 1973 paper in Proceedings of the National Academy of Sciences that forms the basis of the patents. He has consistently refused to sign a disclaimer of co-inventorship as requested by Stanford University and the University of California, but decided only last week to press his claim actively.

The decision seems likely to delay further the issuing of the second CohenBoyer patent, at present in limbo after the patent office tentatively rejected it, in part because of the unresolved role of Helling. It may also increase pressure for a reexamination of the first patent, issued in December 1980.

The decision last week came after the University of Michigan agreed to take up the case on Helling's behalf. James Dautremont, the university's intellectual property counsel, said the matter would be discussed with both the patent office and the two universities involved "in a completely cooperative effort to determine where the legally proper inventorship lies"'.

It is not clear whether Helling or the University of Michigan has a financial stake in the outcome. Helling did sign a patent agreement with the University of California covering his term there that appears to assign any patents to that university; if that is so, all he could gain would be the recognition of having his name added to the landmark patents. On the other hand, if it turns out that he was covered by the University of Michigan's patent regulations at the time, he would divide his share of the royalties equally with the University of Michigan.

In the response of 1 November to the patent office's proposed rejection of the second patent, the attorney for Stanford and the University of California argued that Helling's failure either to claim or to disclaim co-inventorship in the eight years since the patents were filed should not

be permitted to hold up the patent. But Dautremont counters that "inventorship can be challenged or modified as appropriate according to the facts at any time". The question, he says, is whether "Professor Helling in fact made a significant contribution to the invention as recited in the claims of the patent. I'm sure that will become clear from written records, lab notebooks, and so on"'.

Dautremont emphasized that "we're not in a fight at all" and said he expected the matter to be resolved "amicably". And he suggested that it would be in the best interests of Stanford University and the University of California to add Helling's name to the patent if the facts warrant it in order to remove a "cloud over this issue".

Stephen Budiansky

\title{
Strike response to French reform
}

The plans of M. Alain Savary, French minister of national education, to set in motion what he described in early October as a "global reform" of the universities and their prestigious sisters, the grandes écoles, seem to be meeting with an equally global resistance.

The university trade union SNE-Sup (Syndicat National de l'Education Supérieure) has this week, therefore, called a two-day national strike, demanding that the reform be given "new life"; while the grandes écoles, engineering schools well represented in the government administration and traditionally regarded as providing the best education in France, have been applying their own behind-thescenes pressure to ensure that real life does not affect them. Given M. Savary's gentlemanly approach to politics, the result

\section{IIASA struggles on in hope}

The International Institute of Applied Systems Analysis (IIASA), the EastWest systems analysis centre in Vienna, has had a reprieve from the United States, and a partial reprieve from Britain.

In both countries, the member institutes of IIASA - the National Academy of Sciences in the United States and the Royal Society in the United Kingdom - had withdrawn as of 1 January 1983, and the problem was to find new members that could pay the subscriptions for IIASA's total budget of around $\mathrm{E} 5$ million (in 1981). Now the American Academy of Arts and Sciences has agreed to take over the US membership, raising the money needed from private foundations and industry.

In Britain, the situation is less clear. The Fellowship of Engineering, a body with few funds of its own, is debating whether to join IIASA, but it will have to find the whole subscription outside either in industry or in government departments other than the Department of Environment, which originally paid the bill and whose lack of interest in IIASA led to the Royal Society's withdrawal.

Meanwhile, IIASA - crossing its corporate fingers - has drawn up its research plans for 1983. Project titles include: patterns of economic structural change and industrial adjustment; national agricultural policies; energy development, economy, and investments; structural change in the forest sector; institutions and environmental policies; population - ageing and changing lifestyles; integrated regional and urban development; adaptation and optimization; and negotiations and interactive decision making.

Robert Walgate may be something closely approaching the status quo.

Meanwhile, the water is being muddied by the ministry, which appears reluctant to reveal exactly what the minister has in mind. First, there is the unpublished - but circulating - "Jeantet report", described by conservatives as the work of a "radical dreamer". It foresees the absorption of some grandes écoles by the universities, and attacks élitism. It is the result of $\mathrm{M}$. Claude Jeantet's questionnaire to the universities, grandes écoles and other institutions and was intended to form the basis of the reform, but it now it seems the minister is distancing himself from it.

Then there are three other texts, all published within two weeks in October, which purport to outline the minister's views. Two of these are speeches by Savary himself, and one - the last - is an "information note" from the ministry. All are partly contradictory. They appear to indicate an evolution towards conservatism; but the information note fails to touch on many key issues - such as research, or reform of higher degrees and leaves room for the reform to be radical in some respects. (For example, universities are defined as including "schools" - by implication the grandes écoles - but grandes écoles are also defined outside the universities; thus grandes écoles directors are asking themselves which kind of school their own will be.)

As if further to confuse the issue, the director-general for higher education and research at Savary's ministry, the newlyappointed and activist $M$. Jean-Jacques Payan, said last week that he had been taken fully into Savary's confidence over the final shape of the reform and that it will reveal "many new things" when it is published, he predicts, on 10 December. For example, he says, the reform will allow 